\title{
- \\ The Effect of Gaseous Ozone Generated by Surface Dielectric Barrier Discharge on the Decay and Quality of Stored Onion Bulbs
}

\author{
Junghyun Lim ${ }^{+} \mathbb{D}$, Jong-Seok Song ${ }^{+} \mathbb{D}$, Sangheum Eom, Jung Woo Yoon, Sang-Hye Ji, Seong Bong Kim \\ and Seungmin Ryu*
}

check for updates

Citation: Lim, J.; Song, J.-S.; Eom, S.; Yoon, J.W.; Ji, S.-H.; Kim, S.B.; Ryu, S. The Effect of Gaseous Ozone Generated by Surface Dielectric Barrier Discharge on the Decay and Quality of Stored Onion Bulbs. Agronomy 2021, 11, 1058. https:// doi.org/10.3390/agronomy11061058

Academic Editors: Koichi Takaki,

Nobuya Hayashi, Douyan Wang and Kazunori Koga

Received: 28 April 2021

Accepted: 21 May 2021

Published: 25 May 2021

Publisher's Note: MDPI stays neutral with regard to jurisdictional claims in published maps and institutional affiliations.

Copyright: (c) 2021 by the authors. Licensee MDPI, Basel, Switzerland. This article is an open access article distributed under the terms and conditions of the Creative Commons Attribution (CC BY) license (https:// creativecommons.org/licenses/by/ $4.0 /)$.
Institute of Plasma Technology, Korea Institute of Fusion Energy, Gunsan 54004, Korea; limjh@kfe.re.kr (J.L.); jongseoksong@kfe.re.kr (J.-S.S.); eomsh@kfe.re.kr (S.E.); yoonjw85@kfe.re.kr (J.W.Y.); sanghye@kfe.re.kr (S.-H.J.); sbkim@kfe.re.kr (S.B.K.)

* Correspondence: smryu@kfe.re.kr

t These authors contributed equally to this study.

\begin{abstract}
An effective and eco-friendly technology is needed to prevent postharvest loss of onion bulbs during cold storage. This study investigated the effect of gaseous ozone on the decay and quality of onion bulbs during storage at $2{ }^{\circ} \mathrm{C}$ and $70 \%$ relative humidity for two months. Gaseous ozone was adjusted to a concentration of $1.27 \pm 0.024 \mathrm{ppm}$ in the storage room by generating a high voltage discharge in air. After two months of storage, gaseous ozone significantly reduced the counts of aerobic bacteria (e.g., Rahnella aquatilis) and fungi (e.g., yeast and mold) in the onion bulbs by 4 log $\left(\mathrm{CFU} \mathrm{g}{ }^{-1}\right)$ and $0.92 \log \left(\mathrm{CFU} \mathrm{g}^{-1}\right)$ compared with those of an untreated control, respectively. The microbial reduction by gaseous ozone resulted in a lower rotten rate of the onion bulbs, which was less than $20.0 \%$ compared with that of the untreated control. Moreover, the ozone exposure extended the storage life of the onion bulbs by delaying its color change and softening during storage. Our results suggest that gaseous ozone can control the decay of onion bulbs safely during storage.
\end{abstract}

Keywords: antibacterial effect; onion; ozone; plasma; postharvest technology

\section{Introduction}

Onion bulbs are commonly stored at low temperature to ensure their good quality during storage [1]. However, their decay often occurs due to postharvest pathogens and results in serious economic loss [2]. Some bacterial pathogens including Rahnella strains are able to cause disease symptoms such as discoloration and softening of the onion bulbs at $5{ }^{\circ} \mathrm{C}[3]$, and other pathogens including fungi cause severe disease such as black mold, blue mold and neck rot in onion bulbs [4]. To prevent these diseases during cold storage, the practical use of sulfur fumigation has been carried out in storage rooms [5]. Although it is effective, the use of sulfur fumigant might be limited due to the adverse effects of its residues on onion bulbs [6,7]. Thus, it is essential to find a non-residual treatment with effective pest control and good safety for onion bulbs during storage.

Gaseous ozone treatment can be an alternative to sulfur fumigation as a way of preserving onion bulbs during cold storage. The gaseous ozone is easily generated when a high voltage discharge is applied to the electrodes in air $[8,9]$. Due to its high oxidation capacity, gaseous ozone treatment has been a tool for microbial decontamination of fruits and vegetables [10-12]. The efficacy of gaseous ozone treatment depends on the concentration of ozone, exposure time, and type of foods [13]. A high concentration of gaseous ozone is effective for microbial decontamination without quality loss of the fruit when shortly applied during short-term storage [14-16]. A low concentration of ozone treatment is reported to effectively control postharvest diseases of fruits and vegetables when continuously applied during long-term storage [17-19]. However, excessive use of ozone is not recommended since it causes negative effects on surface oxidation resulting in 
discoloration of foods [20,21]. The effectiveness of ozone also depends on the different food types. For instance, the populations of Shiga toxin-producing Escherichia coli were reduced by $1.2,0.5$ and $1.6 \log$ (CFU g $\left.{ }^{-1}\right)$ on the surface of carrot, blueberry and tomato when treated with the same ozone concentration for $5 \mathrm{~h}$, respectively. [22]. Although gaseous ozone treatment has been extensively studied for the preservation of fruits and vegetables, few studies have been done on extending the storage life of onion bulbs using ozone gas. Considering the different responses of postharvest crops to ozone, it is necessary to confirm if ozone can control the decay of onion bulbs with good safety during storage.

Therefore, this study evaluated the effect of continuous ozone on the decay and quality of onion bulbs during storage. For the decay of the onion bulbs, microbial population and rotten rate were assessed, and quality assessment was done by measuring the flesh color, firmness, weight loss, and soluble sugar content.

\section{Materials and Methods}

\subsection{Ozone Treatment and Storage Condition}

Fresh onion bulbs were purchased at a local market in Gunsan, South Korea and uniformly selected based on their size and weight (about $300 \mathrm{~g}$ ) with a clean appearance. Five containers (50-L) each containing 60 onion bulbs were arranged in two storage rooms of $24 \mathrm{~m}^{3}$ and subjected to different treatments (Figure 1). Gaseous ozone was prepared by discharging air for $4 \mathrm{~min}$ at an interval of $140 \mathrm{~min}$ with surface dielectric barrier discharge (SDBD) electrodes in the storage room maintaining $2{ }^{\circ} \mathrm{C}$ and $70 \%$ relative humidity. An untreated control and $1.27 \pm 0.024 \mathrm{ppm}$ of ozone were prepared. The concentration of other reactive species such as $\mathrm{NO}$ and $\mathrm{NO}_{2}$ was too low to detect $(<0.01 \mathrm{ppb})$. The same SDBD electrodes were previously reported as a discharge source [23,24], and they generated a high voltage discharge at an average power of $51.7 \mathrm{~W}$ with a driving frequency of $14.4 \mathrm{kHz}$ and a peak-to-peak voltage of $8 \mathrm{kV}_{\mathrm{p} \text {-p }}$ [24]. Each room was fitted with a temperature controller (KDC-2000MR1L, Korea Digital, Gwangju, Korea) and a fan (KUC-SDU030L, Kyungdong, Korea) to maintain a constant temperature and humidity throughout the whole room. The ozone concentration inside the room was daily recorded using an ozone analyzer (UV-100, Eco Sensors, Santa Fe, NM, USA).

(a)

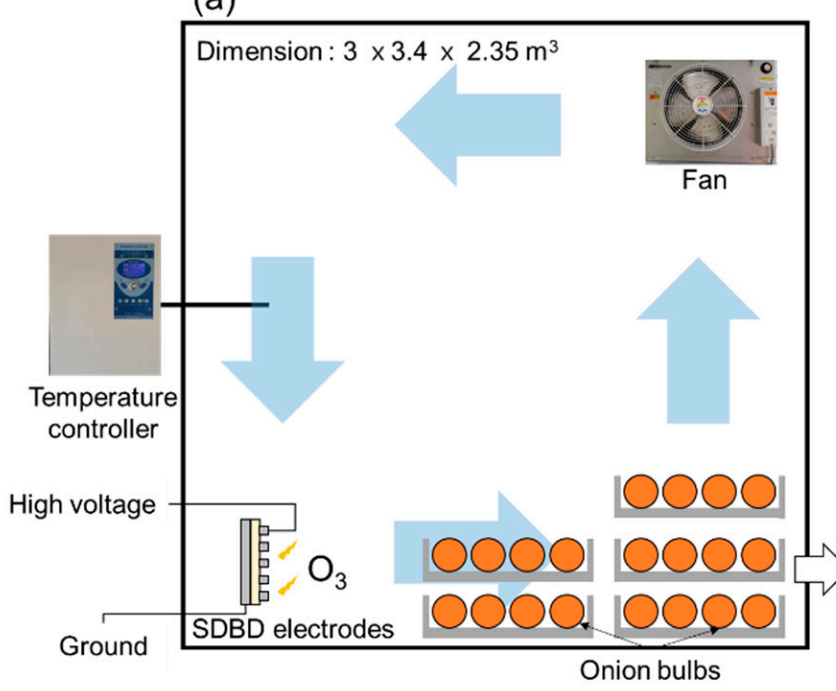

(b)

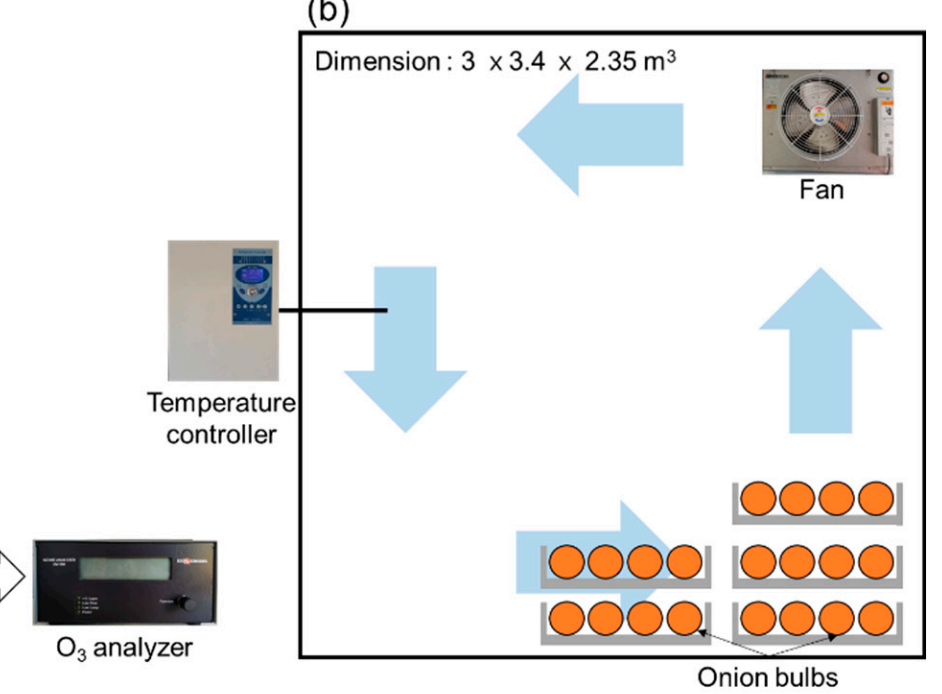

Figure 1. Schematic diagram of the two storage rooms for the ozone-treated (a) and untreated (b) onion bulbs during storage at $2{ }^{\circ} \mathrm{C}$ and $70 \%$ relative humidity.

\subsection{Microbial Analysis}

Total counts of aerobic bacteria and fungi in the onion bulbs were analyzed according to a previously reported method with slight modifications [25]. Five onion bulbs were 
randomly sampled from one container (50-L) for sampling every month. Forty grams of randomly sliced onions were placed into $360 \mathrm{~mL}$ of sterile water in a filter bag (3M, St. Paul, MN, USA) and homogenized at level 5 (5 6 strokes $\left.\mathrm{s}^{-1}\right)$ for 2 min using a stomacher (LS-400, BNF Korea, Gimpo, Korea). The supernatant was diluted 10-fold in sterile 0.9\% saline water (3M, USA). A one milliliter aliquot of each diluted solution was pipetted and placed on aerobic bacterial count and Yeast/Mold count plates (3M Petrifilm, St. Paul, MN, USA). For the aerobic bacterial count, the plate was incubated at $35^{\circ} \mathrm{C}$ for $48 \mathrm{~h}$. For the yeast and mold count, the plate was incubated at $25^{\circ} \mathrm{C}$ for 5 days.

A dominant strain was isolated for identification. Genomic DNA of the strain was extracted using the QiaAMp DNA mini kit (Qiagen, Hilden, Germany). Amplification of the $16 \mathrm{~S}$ rRNA gene of the isolate was performed using the bacterial primers $785 \mathrm{~F}$ (GGATTAGATACCCTGGTA) and 907R (CCGTCAATTCMTTTRAGCTT). The 16S rDNA gene sequences of the bacterial isolate were matched with those from an NCBI BLAST search on 27 October 2020 (http:/ / blast.ncbi.nlm.nih.gov /).

\subsection{Onion Quality Assessments}

All the onion bulbs from each container were analyzed for the rotten rate. Ten onion bulbs were randomly sampled from one container (50-L) for sampling every month and analyzed for discoloration and softening of the onion bulbs. The onion bulbs were regarded as rotten if it showed decay, discoloring, and softening [25]. The rotten rate of the onion bulbs was expressed as a percentage of the total number of rotten bulbs out of the 60 onion bulbs in each container. The discoloration of 5 peeled bulbs was measured using a colorimeter (Model CR-400, Konica Minolta Co., Ltd., Tokyo, Japan); the color change was expressed as the total color difference $(\Delta \mathrm{E})$ which was calculated according to a previous method [26]. The softening of another 5 peeled bulbs was measured using a texture analyzer (EZ-LX, Shimadzu, Kyoto, Japan) equipped with $0.1 \mathrm{kN}$ load cell and cylindrical probe $(\Phi=6 \mathrm{~mm})$. The speed of the cylindrical probe was $5.0 \mathrm{~mm} \mathrm{sec}^{-1}$, and the maximum force was recorded [27]. The measurements of flesh color and firmness were done five times.

For the other quality assessments, 10 onion bulbs were also measured for weight and soluble sugar content. The weight loss of a single bulb was averaged from 10 onion bulbs harvested for each sampling date, and the soluble sugar content of a single bulb was destructively analyzed using a digital refractometer (PAL-1, Atago Co. Ltd., Tokyo, Japan).

\subsection{Statistical Analysis}

All the data were initially subjected to analysis of variance, and a mean comparison was done with Duncan's multiple range test $(p<0.05)$ [27]. All the statistical analyses were conducted using SPSS (IBM, Armonk, NY, USA).

\section{Results and Discussion}

\subsection{Ozone Reduced the Total Counts of Bacteria and Fungi in the Onion Bulbs}

Postharvest pathogens remain quiescent at low temperatures but activate their growth under favorable conditions. In this study, the total counts of bacteria and fungi were measured for the ozone efficacy during two months in a storage room maintained at a concentration of 1.27 ppm ozone in comparison with an untreated control. The ozone treatment significantly reduced the total counts of bacteria and fungi (e.g., yeast and mold) by $4 \log \left(\mathrm{CFU} \mathrm{g}^{-1}\right)$ and $0.92 \log \left(\mathrm{CFU} \mathrm{g}{ }^{-1}\right)$ compared with those of the untreated control at two months of storage, respectively (Figure 2). In particular, the ozone treatment effectively reduced the bacterial counts much more than those of the fungal counts. It might be attributed to the structural differences of bacteria and fungi. It was previously reported that gram-negative Pseudomonas aeruginosa and gram-positive Enterococcus faecalis showed susceptibility to gaseous ozone due to weak cell walls compared with the fungus Candida albicans [28]. In this study, R. aquatilis, which was dominant in the onion bulbs, was reduced 
to $0.5 \log \left(\mathrm{CFU} \mathrm{g}^{-1}\right)$ when applied with ozone at $1.27 \mathrm{ppm}$ in the storage room. Thus, ozone treatment can be effective to reduce the total counts of aerobic bacteria in onion bulbs.

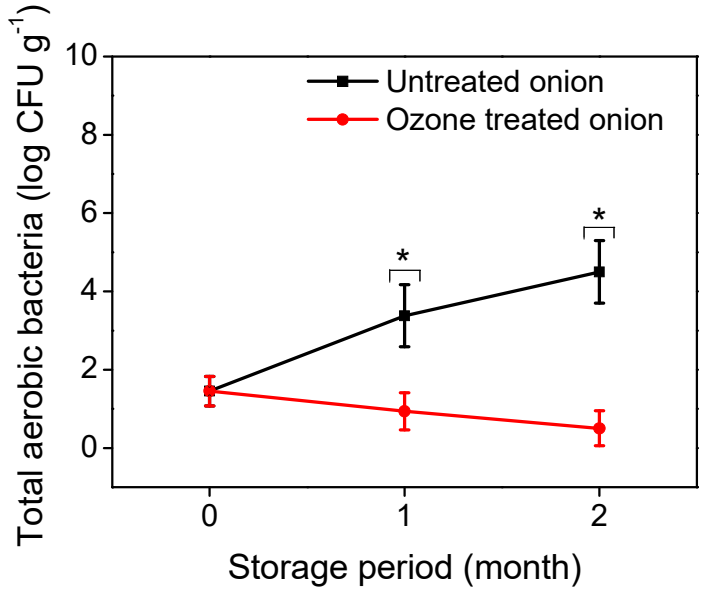

(a)

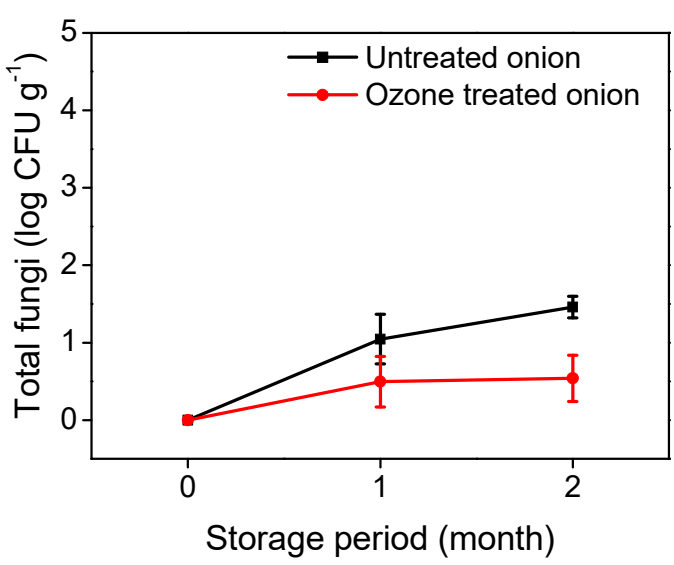

(b)

Figure 2. Total counts of the aerobic bacteria (a) and fungi (b) in the ozone-treated (red circle) and untreated (black square) onion bulbs during two months of storage at $2{ }^{\circ} \mathrm{C}$ and $70 \%$ relative humidity. Each symbol represents the mean of five replicates with each replicate derived from one bulb. Error bar represents the standard error of that mean. An asterisk means a significant difference between the untreated and ozone-treated onion bulbs at each month $(p<0.05)$.

\subsection{Ozone Reduced the Degree of Rotting of the Onion Bulb with Less Color Change and Softening}

The rotten rate of the onion bulbs was assessed for its decay caused by postharvest pathogens during storage. The ozone treatment significantly reduced the rotten rate of the onion bulbs during the two months of storage. It was approximately $20 \%$ less for the onion bulbs treated with the ozone compared to the untreated control at two months (Figure 3). The discoloration and softening of peeled bulbs were also assessed for onion quality as affected by postharvest pathogens during the two months of storage. The ozone treatment significantly reduced the total color difference and softening of the onion bulbs. The total color difference and softening were $20.5 \%$ and $12.9 \%$ less for the onion bulbs treated with the ozone compared to the untreated control at two months (Figure 4). In this study, there was no or little change in temperature and humidity in the two storage rooms for the ozone-treated and untreated onion bulbs. The results of this study indicate that the reduction of rotten onion bulbs might be a result of the reduced counts of R. aquatilis by the ozone treatment during the two months of storage. It was previously found that scale discoloration and shrinkage appear when $R$. aquatilis is present with other pathogens in onion bulbs [3]. About $30 \%$ of onion bulbs are reported to be rotten due to pathogen invasion, suggesting that synthetic fungicides, bio fungicides or other novel methods should be used to reduce postharvest loss of onion bulbs [29]. In this study, it was observed that the total number of $R$. aquatilis, which was the main microorganism among the bacteria and fungi, was decreased by the ozone treatment. Thus, it seems to be concluded that the changes in onion quality including the rotten rate, color and firmness are probably derived from the reduced number of $R$. aquatilis and fungi by the ozone treatment. 


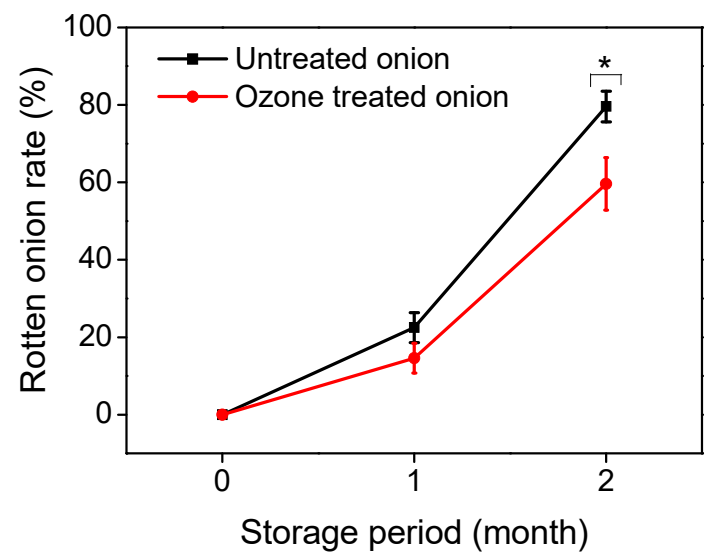

Figure 3. Rotten rate of the ozone-treated (red circle) and untreated (black square) onion bulbs during the two months of storage at $2{ }^{\circ} \mathrm{C}$ and $70 \%$ relative humidity. The rotten rate was expressed as a percentage of the total number of rotten bulbs out of 60 onion bulbs in each container. Each symbol represents the mean of four replicates with each replicate derived from one container. Error bar represents the standard error of that mean. An asterisk means a significant difference between the untreated and ozone-treated onion bulbs at each month $(p<0.05)$.

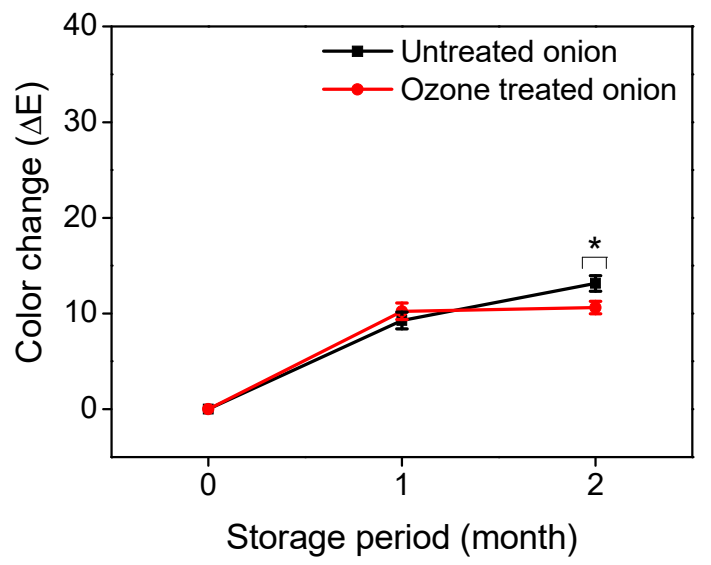

(a)

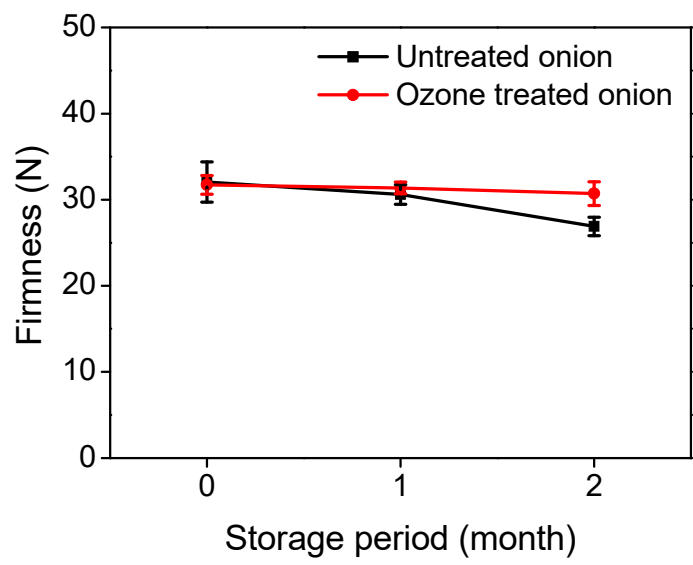

(b)

Figure 4. Color change (a) and firmness (b) of the ozone-treated (red circle) and untreated (black square) onion bulbs during two months of storage at $2{ }^{\circ} \mathrm{C}$ and $70 \%$ relative humidity. The color change and firmness were expressed as the total color difference $(\Delta \mathrm{E})$ and maximum force $(\mathrm{N})$ of the peeled bulbs, respectively. Each symbol represents the mean of five replicates with each replicate derived from one peeled bulb. Error bar represents the standard error of that mean. An asterisk means a significant difference between the untreated and ozone-treated onion bulbs at each month $(p<0.05)$.

\subsection{Ozone Did Not Affect the Weight Loss and Sugar Content of the Onion Bulb}

Bulb weight and soluble sugar content were assessed to determine whether they were affected by the ozone treatment during storage (Figure 5). The ozone treatment showed no significant effects on the bulb weight and soluble sugar content compared to the untreated control. Regardless of the treatment, the bulb weight slightly decreased, and the soluble sugar content increased during the two months. The slight increase in weight loss and total sugar content might be derived from the hydrolytic and metabolic activities of the onion bulbs during ripening, rather than from the ozone effects. These results by the ripening of the onion bulbs correspond to previous findings [30]. 


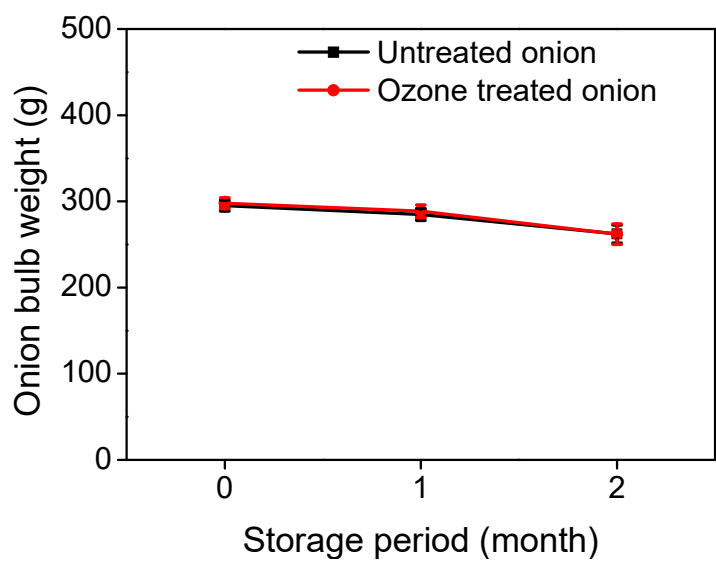

(a)

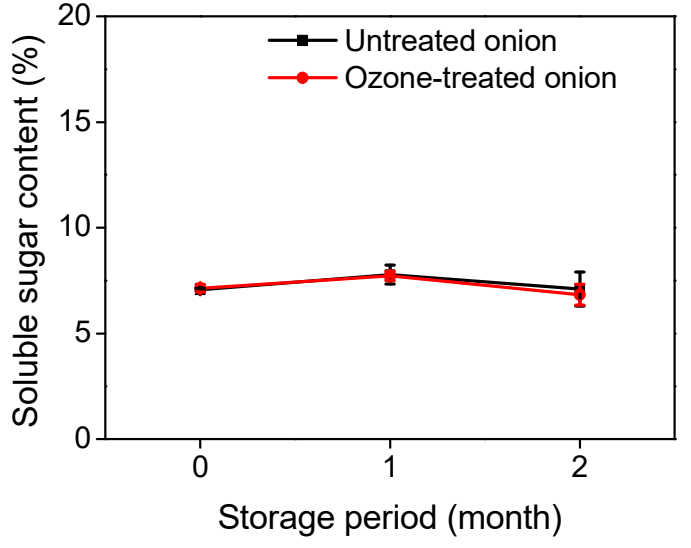

(b)

Figure 5. Bulb weight (a) and soluble sugar content (b) of the ozone-treated (red circle) and untreated (black square) onion bulbs during two months of storage at $2{ }^{\circ} \mathrm{C}$ and $70 \%$ relative humidity. Each symbol represents the mean of five replicates with each replicate derived from one bulb. Error bar represents the standard error of that mean.

\section{Conclusions}

The results of this study indicate that the ozone treatment can be used to reduce the total counts of bacteria and fungi in onion bulbs, thus resulting in reduced rotten bulbs with less color change and softening. Moreover, the ozone treatment caused no significant damage to the onion bulbs during storage. Gaseous ozone at a concentration of about $1 \mathrm{ppm}$ can be used to extend the storage life of onion bulbs without damage. However, to increase the ozone efficacy without damage, its effects on the decay and other sensory properties of onion bulbs must be further investigated in combination with other pretreatment technologies such as water washing. In addition, the safety of the operators still needs to be considered to commercialize storage systems based on gaseous ozone, because a continuous exposure to gaseous ozone is toxic to the operators in a storage room. To protect workers from exposure of gaseous ozone, safety systems such as ozone monitoring, ventilation system and personnel protective equipment have to be used.

Author Contributions: Conceptualization, S.B.K. and S.R.; methodology, J.L. and J.-S.S.; investigation, J.L., J.-S.S., S.E. and J.W.Y.; data curation, J.L. and J.-S.S.; visualization, J.L. and J.-S.S.; formal analysis, J.L. and J.-S.S.; writing-original draft preparation, J.L. and J.-S.S.; writing-review and editing, J.L., J.-S.S., S.-H.J., S.B.K. and S.R.; project administration, S.R.; funding acquisition, S.B.K. All authors have read and agreed to the published version of the manuscript.

Funding: This research was supported by the R\&D Program of the "Plasma Advanced Technology for Agriculture and Food (Plasma Farming; Project No. 1711124797)" through the Korea Institute of Fusion Energy (KFE) funded by the Government funds, Republic of Korea and also supported by Regional Demand-Customized R\&D Support Program (Project No. CN10120JB001) through the Jeonbuk Techno Park funded by the Korea government (MSIT).

Institutional Review Board Statement: Not applicable.

Informed Consent Statement: Not applicable.

Data Availability Statement: Not applicable.

Conflicts of Interest: The authors declare no conflict of interest.

\section{References}

1. Sharma, K.; Lee, Y.R. Effect of different storage temperature on chemical composition of onion (Allium cepa L.) and its enzymes. J. Food Sci. Technol. 2016, 53, 1620-1632. [CrossRef]

2. Zaid, A.M.; Bonasera, J.M.; Beer, S.V. OEM-A new medium for rapid isolation of onion-pathogenic and onion-associated bacteria. J. Microbiol. Methods 2012, 91, 520-526. [CrossRef] [PubMed] 
3. Asselin, J.E.; Eikemo, H.; Perminow, J.; Nordskog, B.; Brurberg, M.B.; Beer, S.V. Rahnella spp. are commonly isolated from onion (Allium cepa) bulbs and are weakly pathogenic. J. Appl. Microbiol. 2019, 127, 812-824. [CrossRef] [PubMed]

4. Maw, B.W.; Seebold, K.W.; Purvis, A.C.; Paulk, J.T. Low humidity, Warm Air Storage Effective For Medium-Term Storage Of Sweet Onions. Appl. Eng. Agric. 2005, 21, 259-264. [CrossRef]

5. Ji, S.H.; Kim, T.K.; Keum, Y.S.; Chun, S.C. The major postharvest disease of onion and its control with thymol fumigation during low-temperature storage. Mycobiology 2018, 46, 242-253. [CrossRef]

6. Kan, W.L.T.; Ma, B.; Lin, G. Sulfur fumigation processing of traditional Chinese medicinal herbs: Beneficial or detrimental? Front. Pharmacol. 2011, 2, 84. [CrossRef]

7. Jiang, X.; Huang, L.; Zheng, S.; Chen, S. Phytomedicine Sulfur fumigation, a better or worse choice in preservation of Traditional Chinese Medicine? Phytomedicine 2013, 20, 97-105. [CrossRef] [PubMed]

8. Li, M.; Yan, Y.; Jin, Q.; Liu, M.; Zhu, B.; Wang, L.; Li, T.; Tang, X.; Zhu, Y. Experimental study on ozone generation from oxygen in double surface dielectric barrier discharge. Vacuum 2018, 157, 249-258. [CrossRef]

9. Song, J.-S.; Kim, S.B.; Ryu, S.; Oh, J.; Kim, D.-S. Emerging Plasma Technology That Alleviates Crop Stress During the Early Growth Stages of Plants: A Review. Front. Plant Sci. 2020, 11, 988. [CrossRef]

10. Khadre, M.A.; Yousef, A.E.; Kim, J.-G. Microbiological Aspects of Ozone Applications in Food: A Review. J. Food Sci. 2001, 66, 1242-1252. [CrossRef]

11. Miller, F.A.; Silva, C.L.M.; Brandão, T.R.S. A Review on Ozone-Based Treatments for Fruit and Vegetables Preservation. Food Eng. Rev. 2013, 5, 77-106. [CrossRef]

12. Prabha, V.; Barma, R.D.; Singh, R.; Madan, A. Ozone Technology in Food Processing: A Review. Trends Biosci. 2015, 8, 4031-4047.

13. Deng, L.Z.; Mujumdar, A.S.; Pan, Z.; Vidyarthi, S.K.; Xu, J.; Zielinska, M.; Xiao, H.W. Emerging chemical and physical disinfection technologies of fruits and vegetables: A comprehensive review. Crit. Rev. Food Sci. Nutr. 2020, 60, 2481-2508. [CrossRef]

14. Misra, N.N.; Pankaj, S.K.; Walsh, T.; O’Regan, F.; Bourke, P.; Cullen, P.J. In-package nonthermal plasma degradation of pesticides on fresh produce. J. Hazard. Mater. 2014, 271,33-40. [CrossRef]

15. Moon, A.Y.; Noh, S.; Moon, S.Y.; You, S. Feasibility study of atmospheric-pressure plasma treated air gas package for grape's shelf-life improvement. Curr. Appl. Phys. 2016, 16, 440-445. [CrossRef]

16. Lone, S.A.; Raghunathan, S.; Davoodbasha, M.A.; Srinivasan, H.; Lee, S.Y. An investigation on the sterilization of berry fruit using ozone: An option to preservation and long-term storage. Biocatal. Agric. Biotechnol. 2019, 20, 101212. [CrossRef]

17. Palou, L.; Crisosto, C.H.; Smilanick, J.L.; Adaskaveg, J.E.; Zoffoli, J.P. Effects of continuous 0.3 ppm ozone exposure on decay development and physiological responses of peaches and table grapes in cold storage. Postharvest Biol. Technol. 2002, 24, 39-48. [CrossRef]

18. Hildebrand, P.D.; Forney, C.F.; Song, J.; Fan, L.; Mcrae, K.B. Postharvest Biology and Technology Effect of a continuous low ozone exposure $\left(50 \mathrm{~nL} \mathrm{~L}^{-1}\right)$ on decay and quality of stored carrots. Postharvest Biol. Technol. 2008, 49, 397-402. [CrossRef]

19. Feliziani, E.; Romanazzi, G.; Smilanick, J.L. Application of low concentrations of ozone during the cold storage of table grapes. Postharvest Biol. Technol. 2014, 93, 38-48. [CrossRef]

20. Brodowska, A.J.; Nowak, A.; Śmigielski, K. Ozone in the food industry: Principles of ozone treatment, mechanisms of action, and applications: An overview. Crit. Rev. Food Sci. Nutr. 2018, 58, 2176-2201. [CrossRef] [PubMed]

21. Kim, J.G.; Yousef, A.E.; Dave, S. Application of ozone for enhancing the microbiological safety and quality of foods: A review. J. Food Prot. 1999, 62, 1071-1087. [CrossRef] [PubMed]

22. Bridges, D.F.; Rane, B.; Wu, V.C.H. The effectiveness of closed-circulation gaseous chlorine dioxide or ozone treatment against bacterial pathogens on produce. Food Control 2018, 91, 261-267. [CrossRef]

23. Song, J.S.; Jung, S.; Jee, S.; Yoon, J.W.; Byeon, Y.S.; Park, S.; Kim, S.B. Growth and bioactive phytochemicals of Panax ginseng sprouts grown in an aeroponic system using plasma-treated water as the nitrogen source. Sci. Rep. 2021, 11, 2924. [CrossRef] [PubMed]

24. Song, J.S.; Lee, M.J.; Ra, J.E.; Lee, K.S.; Eom, S.; Ham, H.M.; Kim, H.Y.; Kim, S.B.; Lim, J. Growth and bioactive phytochemicals in barley (Hordeum vulgare L.) sprouts affected by atmospheric pressure plasma during seed germination. J. Phys. D. Appl. Phys. 2020, 53, 314002. [CrossRef]

25. Bae, Y.; Choi, H.; Lee, J.; Park, M.; Choi, J.; Kim, J. Effect of packing type and storage temperature on microbial growth and quality of fresh-cut onions (Allium cepa cv. turbo). Korean J. food Preserv. 2016, 23, 623-630. [CrossRef]

26. Petropoulos, S.A.; Ntatsi, G.; Ferreira, I.C.F.R. Long-term storage of onion and the factors that affect its quality: A critical review. Food Rev. Int. 2017, 33, 62-83. [CrossRef]

27. Song, J.S.; Yoo, S.K.; Kim, D.S. The effect of 1-(3-phenyl-propyl)cyclopropene versus 1-MCP on the quality and storage life of tomato (Solanum lycopersicum) fruit. Postharvest Biol. Technol. 2018, 145, 20-26. [CrossRef]

28. Nishime, T.M.C.; Borges, A.C.; Koga-Ito, C.Y.; Machida, M.; Hein, L.R.O.; Kostov, K.G. Non-thermal atmospheric pressure plasma jet applied to inactivation of different microorganisms. Surf. Coatings Technol. 2017, 312, 19-24. [CrossRef]

29. Kumar, V.; Neeraj, S.S.; Sagar, N.A. Post Harvest Management of Fungal Diseases in Onion-A Review. Int. J. Curr. Microbiol. Appl. Sci. 2015, 4, 737-752.

30. Salama, A.M.; Hicks, J.R.; Nock, J.F. Sugar and Organic Acid Changes in Stored Onion Bulbs Treated with Maleic Hydrazide. HortScience 1990, 25, 1625-1628. [CrossRef] 